\title{
The Ambivalent Conjunction of Modernity and Human Rights
}

\author{
W. J. Situma
}

ABSTRACT

Modernity is a stage in societies' development that is the corollary of enlightenment. It has variously been conceived to be the ultimate moment in the unfolding of human history in the sense that norms and values, and practices and institutions are nearly or at their most perfect. However, the conceived prelude to or realization of utopia does not accord with reality in many specific modern societies, even those that are generally considered to be the forerunners of modernity. In Africa, the onset of modernity and its extension into the diverse realms of human beings' lives has entailed norms and values, and practices and institutions that are the genesis of dystopia. This article examines the ambivalent nexus of modernity and human rights in Africa from the onset of the modernization project to date. Using critical theory, the article argues that although modernity is credited with the birth of human rights, in Africa its primary actors, namely capital, the markets, and the state, are either ambivalent to and/or causal to widespread and deep human rights violations. The human rights violations are systemically and systematically cast as incidental and spurious rather than the hallmarks of modernity. Judicial, political, and educational institutions act and reiterate their capacities to address the incidental/spurious human rights violations, despite abundant evidence that, as part of modernity, these institutions are ambivalent to human rights and, therefore, can only mask the reality and perpetuate human rights violations. This general stance is the consequence of the pervasive logic of capital. This article explains how this pervasive phenomenon in its various forms, such as state capitalism and global capitalism, coupled with neopatrimonialism, has impacted the institution and practice of human rights in Africa. The analysis concludes that though modernity is credited with the birth of human rights regimes, its historicity has been causal of significant violations of human rights. The violations unleashed by capital are exacerbated by political elites who, in their processes of policy-making and budgetary deliberation, and implementation, marginally conceive nation-extensive notions of common good. Consequently, violation of human rights is rampant.

Keywords: capital, global capital, globalization, human rights, modernity.
Published Online: July 08, 2021

ISSN: $2736-5514$

DOI :10.24018/theology.2021.1.3.19

\section{W. J. Situma}

University of Nairobi, Nairobi, Kenya.

(e-mail: situmasituma@gmail.com)

\section{INTRODUCTION}

Modernity is widely credited with the conception, formulation and establishment of institutions of human rights, and enforcement of human rights [1]; [2]. Indeed, some scholars argue that attempts to trace the genesis of human rights in other times and spaces are misconceived. There is much credence to this argument, granted the definitive notions that inform the UDHR are explicit and loud in no other era and school of thought other than the enlightenment. Enlightenment thinkers argue that modernity and its distinctive norms and values, practices and institutions were inevitable outcomes of the unfolding of social history (Kant, Hegel, and Marx and Engels). Niklas [3] espouses a contrary view: that modernity and its essential institution of human rights and the features of differentiation are contingent and fragile. In any case for both historicist enlightenment thinkers and the sociological Luhmann, human rights are a subset of norms and values, practices and institutions that are an essential and a definitive facet of modernity. If that is the case, then what is ambivalent about the conjunction of modernity and human rights?

Modern society originated from the decline and in some places the overthrow of the feudal society and the ascendency of the bourgeoisie and establishment of liberal democracy as the political dispensation and capitalism as the economic mode. Luhmann conceives liberal democracy and capitalism to constitute a distinctive individuality that is unfamiliar, unpredictable, and strange. This is because the modern persona defines and keeps on redefining itself by exercising fundamental freedoms and human rights at every point. 
On the other hand, [4] and [5] argue that while modern society was initially characterized by emphasis on capital in the economic realm and the spirit in the political, cultural, and community spheres, the former aspect has become dominant. Thus, in his analysis of Luhmann, [2] points out that while Luhmann is alive to the totalizing tendency of the political subsystem, Chrstoph Beat Graber and Gunther [6] point out that the economic and technological subsystems have the potential to be equally totalizing and therefore to endanger the fundamental freedoms and human rights through totalizing dynamics in the contemporary modern world. In fact, while in the inceptive stages of the modern society there was some degree of balance between capital and the spirit, in contemporary modern society the logic of capital pervades every corner of human life. One pertinent outcome of the pervasive extension of the logic of capital to all activities of human beings' lives is the preference of abstraction and quantification in the social sciences and humanities. The totalizing logic of capital is also evident in politics, religion, inter-subjective affairs, and of course in the production, distribution, and consumption of values. Thus, Luhmann's conceived functional differentiation, which is supposed to ensure exclusion of human beings from society and in the process secure and offer them freedom to participate in the various functional subsystems, does not quite hold.

Part I of this article examines the ramifications of the pervasive logic of capital on human rights. Then, in Part II, the article focuses on modernity and human rights in Africa. From the analyses, the article draws various conclusions.

Modernity is widely credited with the conception, formulation and establishment of institutions of human rights, and enforcement of human rights [1]; Luhmann. 1957, 1993; [2]. Indeed, some scholars argue that attempts to trace the genesis of human rights in other times and spaces are misconceived. There is much credence to this argument, granted the definitive notions that inform the UDHR are explicit and loud in no other era and school of thought other than the enlightenment. Enlightenment thinkers argue that modernity and its distinctive norms and values, practices and institutions were inevitable outcomes of the unfolding of social history (Kant, Hegel, and Marx and Engels). [3] espouses a contrary view: that modernity and its essential institution of human rights and the features of differentiation are contingent and fragile. In any case for both historicist enlightenment thinkers and the sociological Luhmann, human rights are a subset of norms and values, practices and institutions that are an essential and a definitive facet of modernity. If that is the case, then what is ambivalent about the conjunction of modernity and human rights?

Modern society originated from the decline and in some places the overthrow of the feudal society and the ascendency of the bourgeoisie and establishment of liberal democracy as the political dispensation and capitalism as the economic mode. Luhmann conceives liberal democracy and capitalism to constitute a distinctive individuality that is unfamiliar, unpredictable, and strange. This is because the modern persona defines and keeps on redefining itself by exercising fundamental freedoms and human rights at every point.

On the other hand, [4] and [5] argue that while modern society was initially characterized by emphasis on capital in the economic realm and the spirit in the political, cultural, and community spheres, the former aspect has become dominant. Thus, in his analysis of Luhmann, Verschraegen [2] points out that while Luhmann is alive to the totalizing tendency of the political subsystem, [6] point out that the economic and technological subsystems have the potential to be equally totalizing and therefore to endanger the fundamental freedoms and human rights through totalizing dynamics in the contemporary modern world. In fact, while in the inceptive stages of the modern society there was some degree of balance between capital and the spirit, in contemporary modern society the logic of capital pervades every corner of human life. One pertinent outcome of the pervasive extension of the logic of capital to all activities of human beings' lives is the preference of abstraction and quantification in the social sciences and humanities. The totalizing logic of capital is also evident in politics, religion, inter-subjective affairs, and of course in the production, distribution, and consumption of values. Thus, Luhmann's conceived functional differentiation, which is supposed to ensure exclusion of human beings from society and in the process secure and offer them freedom to participate in the various functional subsystems, does not quite hold.

Part I of this article examines the ramifications of the pervasive logic of capital on human rights. Then, in Part II, the article focuses on modernity and human rights in Africa. From the analyses, the article draws various conclusions.

\section{PERVASIVE LOGIC OF CAPITAL AND ITS RAMIFICATIONS ON HUMAN RIGHTS}

What is the logic of capital? The phrase logic of capital refers to the Marxist conceptualization of the processes that capital imposes on all human beings within its ambit, e.g., the owners of capital, the bourgeois, the workers, the peasants, and the lumpenproletariat. Within that framework, capital is conceived to dictate certain patterns of behaviour on each of these categories of human beings. It dictates that owners of capital seek to maximize their investment by all means; that workers are compelled to work longer and longer hours by their employees and by their own reproductive needs; that lumpenproletariat are always ready to be hired at rates lower than those that are going at a particular time; that peasants are progressively sucked into the spheres of capital; and that the bourgeois are compelled to play various roles in ensuring that the significance and necessity for capital is understood and preserved. Moreover, the logic of capital enmeshes even the previously mystical world of religion. The resulting pervasive state has grave ramifications on human rights.

First, although the owners of capital have juridical liberty to dispose of their property, in reality their liberty is substantially constrained. The capitalist cannot significantly ensure enjoyment of better wages by their workers. In fact, as (5) observes, they are "driven by the impulse to expand their wealth", but they are "neither responsible for the peculiar causality that is sustaining modern society, nor are they in control of it". Nevertheless, the individual owners of capital are bound to be averse to any agitation for better wages because that directly threatens the possibility of expanding wealth, viz. reproduction of capital. Moreover, owners of capital are bound to explore ways of ensuring greater efficiency. This leads to "the eclipse of ends in the face of 
rampant instrumental reason, exacerbated individualism and political atomism [7] and soft despotism [8]. It follows from this that recommendations such as those of the Special Representative of the United Nations Secretary-General on Human Rights and Transnational Corporations and other Business Enterprises that corporations must exercise enhanced due diligence "in states with weak government institutions" only address instances where "enterprises tend to exploit such situation when conducting their operations" [9].

Second, while the modern state starts off on the lofty platform of civic duties by those who serve in public offices, the virtues that are necessary for steadfast undertaking of civic duties are progressively corroded by the capitalists' greed for lucrative investment opportunities. The competition that is initially largely an aspect of the markets invades the political arena, and the result is political competition driven by massive finances from questionable funders. Consequently, the state, legislators and even the courts that are supposed to ensure policies and budget profiles, legislations, and verdicts that secure human rights act adversely against human rights clamor. Aside from being compromised to various degrees, as Rendel observes "both those who resist and those who demand reforms...invoke the law, the former wishing to maintain the existing law and the latter demanding new laws" [10].

Third, arising from the fact that states-parties that have the primary duty of "ensuring enjoyment of certain aspects (have) been perceived to fail or refuse to do what (they) ought to do" [11] and in some instance to be the primary violators of human rights, there have emerged non-governmental human rights organisations and international human rights to monitor and ensure observance of human rights in various jurisdictions across the biosphere. However, the NGOs are not immune to the corrosive touch of capital. Thus, [12] notes that NGOs are so averse to negative exposure that most of them eschew participating in studies on corruption in their organizations.

Fourth, in some instances, it is the pervasive hand of capital arising from states' involvement in the economic sphere that accounts for the dereliction of the primary duty. Thus, Agarwala examines "how the Indian state used informal workers as a political actor (not just an economic actor) to organize consent for a powerful hegemonic project of market reforms...that undid labor's twentieth-century gains and empowered large businesses" [13]. While Agarwala argues that the workers in India have achieved better protection and emancipation relative to their counterparts in the past, she also observes that the relationship between the state and society oscillates between collaboration and contestation. Collaboration when the state seeks to manufacture political consent.

Fifth, while from the perspective of critical theory it is pervasive logic of capital that erases the distinction between substructure and superstructure, the causal relationship between these two aspects is complex. This is evident from the fact that although there is hardly a realm that is not permeated by capital, it is unjustified to assert distinction of the base (tools, land, and raw materials) from the superstructure (more so, art, media, science and education and culture). Media is a commodity [14], and a tool and a channel [15]. However, in contemporary society, science and education are the handmaiden of capital. The sciences and entire systems of education have never been as focused as today on ensuring competitive edge, better returns to capital investments through efficiency and effective production models and synchronizing education to the demands of markets. Aside from the positive emphasis on creativity, critical thinking, communication, and collaboration [16], the capitalistic demand for quick and quantifiable results is a sure danger to education [17]. The current policy focus on labor market driven policies in higher education have led to an ever growing competition transforming this social institution to an ordinary market-place, where attainment and degrees are seen as a currency that can be converted to a labour market value" (2017).

Moreover, in modern society, culture is commodified [18] and even the source of commodities. Thus, [19] observes that in Baudrillard's view, "Universal values have become commodified and sold around the world as if they were consumer goods...All [political] liberties fade before the mere liberation of exchange". Therefore, culture is equivalent and, in some instances, greater than land and the raw materials that Marx conceived. Lay and Wallace conceive commodities, raw materials, and the market as culturally constructed aspects. Even if that is true, ultimately cultural construction is done in accordance with the dictates of capital. The net effect of the totalizing logic of capital, particularly the erasure of the distinction between thesis and antithesis, is that the dialectics on which Marx and Hegel predicated qualitative progress from one stage to another are not feasible. Indeed, Dipesh Chakrabarty argues that in view of fact that Marx's assumption of capital by its own logic progressing to dissolution has not been borne out by history, it does not make sense to think of the 'beyond of capital'...when everything in the world seems to be coming more and more under the sway of capital itself" [20]. The net effect of the apparent neutering of 'the beyond' is "ideological monoculture and erosion of socio-economic diversity" ( Encyclopedia of World Problems and Human Potential", intellectual monoculture [21] and the latter extents to policymaking and implementation [22].

Sixth, the corollary that follows from the fifth argument is that processes of "constructing life-histories" are marginalized by research funding agendas that aim at understanding phenomena that are conceived as directly connected to optimization of capital, such as the market, consumer behaviour, and economic growth projections. Granted the importance of life-histories in enabling "people living in modern societies (to) provide their lives with unity and purpose by constructing internalized and evolving narratives" [23], marginalization of this activity means that some people, communities, and nations have no clear idea of their identity. Instead, researchers are compelled to pursue research topics and to employ research methods that are in synchrony with capital, hence abstraction and quantitative research approaches. Moreover, since capital is used in transacting specific aspects (a feature that is perceived to reflect the efficiency of capital), labour is generally highly specialized, and research exempted from this feature of modernity. The consequence is fragmented epistemic accounts of human beings and their plight. In any case, the 
capitalistic emphasis on efficiency entails rashed research conceptualization, implementation, and conclusion. Generally, researchers hardly get to the root of the subject/object they purport to study. The Encyclopedia of World Problems and Human Potential captures this feature as follows: "Research methodologies are too often employed superficially, simply to describe and categorize within the well-trodden arena of the possible, believable or assimilative. They do not synthesize and interpret data in such a way as to expand society".

Notwithstanding the above arguments, the pervasive logic of capital has also enabled billions of people worldwide to access their fundamental freedoms and human rights through mass production of goods such as foodstuffs, clothes, pharmaceuticals, surgical equipments, work and production equipments cars, and telecommunications gadgets such as phones and internet access. Respectively, access to these aspects means that generally more human beings are able to enjoy the right to food, the right to decent clothing, the right to healthcare, the right to a human working environment, and freedom of speech. Thus, compared to their ancestors, human beings in the 21 st Century have the wherewithal to enjoy their various fundamental freedoms and human rights. Derrida notes that, "The discourse in favour of globalization speaks about global interconnectivity made possible through teletechnologies, the opening of borders and markets, the equality of opportunity for all people, the universal accumulation of wealth". He, however, shares Baudrillard's position, that "...there has never been in the history of humanity, in absolute numbers, so many inequalities" and that it is not true that global capitalism is creating a world in which everyone enjoys access to economic goods.

Nevertheless, [24] argues that globalization is not inherently wrong-headed. This is a position that [25] and [26] share. In view of the apparent fact that globalization is not reversible, [27] argues that "...the question that needs to be addressed is how we can better govern this process to make it more inclusive and fairer than the current conditions."

In the next part of this article, the conjunction of modernity and human rights in Africa sub-Sahara is examined and the question of governance addressed.

\section{MODERNITY AND HUMAN RightS IN AFRICA}

At its inception into the sub-Saharan African space, modernity imposed alien practices without reference to human rights and abrogated proto-rights, such as women's proto-right to access and use land resources. Aside from the fact that capital and its logic were alien to the sub-Saharan societies, the introduction of modernity was done under the aegis of "the reformation of (or enlightenment) of natives' minds [28], which is also referred to as mission civilizatrice [29]. In the process, crucial aspects of various communities, e.g., land, minerals, forests, and labour, were forced into the strait-jacket of capital through rafts of statutory acts and brute force.

That advent of modernity and its corollaries, namely the rule of law, its concept of right (both in the sense rectitude and entitlement), and the exclusion of Africans from entitlement to fundamental freedoms and human rights that are conceived to be universal and inalienable set the stage for the issues that have been at the heart of human rights discourse and practice. The universality of fundamental freedoms and human rights is a recurrent issue that elicits various positions: universalism, relativism, and 'realism'. What are concerns with regards to the principle of universality of human rights?

One concern is that granted human rights are grounded in moral and epistemological conceptions, and granted moral and epistemological conceptions are society-specific, how can human rights that are formulated largely on the basis of Western ethos be universal? Thus, Renteln argues that "every society or culture is a self-contained system that defines its own standard of rationality; thus, there are no neutral moral data" [30]. In a similar vein, [31] argues that "cultural and ethical relativism is inevitable because ideas are not transferable in their authenticity and in the final analysis cultures are different because they are associated with different modes of thought." These concerns had to be accommodated in the Vienna Declaration in part 1, para 5, which recognized "the significance of regional particularities," and required that "historical, cultural, and religious backgrounds are borne in mind". There is, moreover, the postmodernist dismissal of universalism as a direct outcome of the Enlightenment grand narratives and emphasis on historicity of conceptions, norms, and values.

Although [32] grants that these relativist contenders have a point in their concern for authenticity and communitarian values that are credited to the traditional African way of life, he argues that they ultimately do not provide "credible vision of society grounded on adequate conception of humanity". In fact, it is Ilesanmi who fails to offer rebuttal to the robust, systematic conception of society and human life that is offered by, among others, Alasdair MacIntyre, Micheal Sandel, and Charles Taylor. In considering modernity and human rights in sub-Saharan countries, the necessity for virtues cannot be gainsaid. In Part I, this article argued that modernity started off with the state as the guarantor of human rights and that the civic virtues for fulfilling these obligations were progressively eroded. In Africa civic virtues have never been cultivated. On the contrary, in colonial, post-colonial, and contemporary it is uncivil attributes such wanton diversion of public resources to personal and cronies' use, neglect of duty, abuse of office, and suppression of citizens' clamour for their rights and their oppression that have been cultivated intergenerationally.

In any case, do we find in sub-Saharan states a distinction of the base from the superstructure? In Part I, it emerged that from the totalizing impact of capital aspects such as science and education, religion, morality, and culture are caught up in the logic of capital. The encompassing operation of capital means that even though the framers of the Universal Declaration of Human Rights, led by Rene Cassin, and subsequent international human rights covenants recognized the importance of culture and even posited cultural rights, that has not secured the latter rights. Aside from the general reasons presented in Part I, in Africa, diverse cultures pose various threats to human rights. Although it is easily granted that each culture and religion contains important humanistic elements [33], both aspects endorse certain practices that challenge and even contradict human rights principles [34]. The tension between the principle of universality and 
historicity aside, there is the concern about the status of the tenets of human rights that Rene Cassin conceived as four pillars, namely, dignity, liberty, equality, and brotherhood vis-à-vis the pervasive capital. In Part I, the effects of pervasive or totalizing capital were examined generally.

In the sub-Saharan societies, after its inception, capital replicated what it had wrought in Western Europe and elsewhere; its logic gradually extended to most spheres of societies. However, while in Western Europe the transition from pre-modern society to modern society was gradual, in sub-Saharan Africa modern institutions and practices were violently imposed and enforced. Therefore, inceptive modernity, with its juggernaut that is capital, considered human dignity, liberty, equality, and brotherhood in highly racialized terms. If in Western Europe modernity was associated with "rapidly proliferating experiences of dissonance that increased individuals' determination to hold onto politics, culture and society as dimensions that provide a semblance of stability", in Africa the dissonance was deeper and more widespread because at that moment and subsequently, politics, culture, and society are expedient and riddled with contradictions. This latter fact means that in Africa there are no dimensions that "provide a semblance of stability". Expediency and contradictions in Africa arise from the fact that although capital was introduced and is unremittingly infused into the space, the patrimonial foundations of most societies remained and therefore neopatrimonialism significantly determines social relations and activities of production, distribution and consumption of values.

In other words, the modernity that is prevalent in African societies is fundamentally different from the modernity of Western Europe and North America. While it is normal for formal and informal institutions, norms, and practices to coexist, in most sub-Saharan African societies patrimonial authorities and dynamics undermine modern institutions, norms and practices [35]. Specifically, and combined with some other factors [36], neo-patrimonial networks divert public resources into private accounts and undermine states' "ability to effectively manage development processes and provide universal public goods and services" [37]. Human rights studies in universities highlight citizens' lack of access to healthcare, education, clean water, decent shelter, employment, and social security, and in some instances worsening access to these aspects that are the heart of social and economic rights. In his study of sub-Saharan societies, O’Neil details how neopatrimonialism spawns weak or no separation of public and private spheres, vertical relationships, clientelism, and the big-man syndrome. The net effect of these features in the modern societies in Africa is that the state is perceived more as a vehicle for wealth acquisition than an impartial guarantor of human rights.

One might wonder how the state in sub-Saharan Africa evolved into a vehicle for wealth acquisition. The fact is, the colonial formations in the sub-continent laid the foundation for the post-colonial state. It is, therefore, not surprising that the postcolonial state performs dismally as a guarantor of human rights. Sub-Saharan states borrow trillions of dollars from global capital through IMF, IFC, World Bank and capitalist countries in the West and East, and channel significant portions of it into personal accounts and on absurd expenditures. The consequence is that unjustified inequalities are exacerbated through largesse, huge taxes that states levy in order to pay the debts, and lack of access to social and economic rights in public institutions. Thus, despite the fact that the establishment of the 'modern state' in Africa has been coterminous with states parties being signatories of international human rights law, African states have been the worst violators of human rights. The political elite wield and utilise state machinery and resources to amass wealth, build networks of clientele, and compromise institutional procedures.

In addition to violations of socio-economic rights arising from the nature of the sub-Saharan states, civil and political rights too are imperiled. Thus, Ajulu observes that, "The kleptocratic and predatory elite associated with the Kenyan state have relied on repressive apparatuses rather than representative institutions as instruments of legitimating their class" (37). While democratic institutions are commendable channels of legitimation, that is on condition that the quantity of representation is justifiable, and that the quality of representation is good. On the aspect of quantity of representation, Auriol and Gary-Bobo started from the position that, "Having too few members of parliament means parliament is likely to be unrepresentative, but it seems having too many makes it easy for vested interests to buy influence" [38]. In their research, the two found, "Empirical work suggests that nations with a much higher number of MEPs tend to be plagued by red-tape and corruption [36]. That finding, coupled with the finding that there is little correlation between high representation and quality of deliberation and legislation, is evident in Kenya. However, something else plays out in the case of Kenya's calculation of representation. Certainly, it is not Auriol and Gary-Bobo's simple logic. Rather it is the metamorphosis of neopatrimonialism from bare-knuckled authoritarianism of the first four decades after independence to a subtle authoritarianism that creates superfluous constituents under the guise of ensuring representation, when the underlying motive is to cultivate patronage.

Moreover, ambivalent conjunction of modernity and human rights arise from the fact that though African governments have the primary duty of protecting and promoting human rights, they are hardly able to protect their citizens from human rights violations by multinational corporations. As earlier observed, global capital is causal to violations where institutions of governance are weak and given that governance institutions are weak in Africa it is not surprising that human rights violations are widespread. Indeed, the expansion of free markets and the operation of capital stands out as continuity of the imperialist project [39].

However, to understand the imperialist project in contemporary sub-Saharan countries better, it is necessary to use De Tocqueville's concept of soft despotism. While imperialism in the eighteenth and twentieth centuries was violent and oppressive, in the post-independence era of subSaharan states, it is subtle and calculated and it rides on the crest wave of enabling African states to fulfill their obligations as states-parties to various human rights covenants and conventions. [40] describes this condition as follows: "It would be like the authority of a parent if, like that authority, its object was to prepare men for manhood: but it 
seeks to keep them in perpetual childhood...For their happiness such a government willingly labors, but it chooses to be the sole agent and the only arbiter of that happiness; it provides for their security, foresees and supplies their necessities...directs their industry...what remains, but to spare them all the care of thinking and all the trouble of living". Clark concludes that in De Tocqueville's account the ultimate consequence of soft despotism are human beings being transformed into "a flock of timid and industrious animals, of which the government is the shepherd". In this conception, the African state is a shepherd in the service of global capital. Their role is to ensure a sense of satisfaction and security to their citizens, and to put in place regulations that ensure minimal disruption of production processes. In view of the soft despotism, it is inconceivable that sub-Saharan governments can prioritize significant development of intellectuals. Certainly, timid, and industrious animals are far from human beings who have dignity and who are capable of authentically exercising the fundamental freedoms and human rights that are stipulated in the UDHR, the ICCPR and ICESCR, among others.

The conjunction of modernity and human rights is also ambivalent, if not paradoxical, due to a number of factors; the flow of capital, expediency-mode of the primary human rights' duty-bearers in sub-Saharan continent; and superficial understanding of human rights and human rights principles.

Capital flows undermine democratic processes and generate regimes that are captive to their sources of funding. Thus, [41] argue that unregulated flows of money in the funding of political parties and election campaigns threaten key democratic principles and values... When politicians and political parties focus more on financiers than public interests and needs, service delivery may be compromised for political expediency". Indeed, Tocqueville argues that in the lead-up to soft despotism, the balance of property increasingly determines the balance of political power. In pointing to this danger, Tocqueville echoes Aristotle and Montesquieu, who argued variously against dispensation in which legal property is allocated as per the discretion of a state. The danger is evident in Kenya, where the state has invariably engaged in allocation of land to ethnics and cronies of those in power, and in the process politicised land and precipitated conflicts [42], [43]. This means that the modern entity called the state is the genesis of violations of socio-economic rights and violations of the fundamental right to life. The threat that states pose on citizens negates the civil and political rights.

The tendency of states to menace citizens also arise from the fact that most of the states in sub-Saharan Africa are often on expediency-mode due the fragile nature of the institutions. If a state is to be a consistent bearer of the duty of ensuring observance of human rights, its agents must of necessity be guided by principles such the Kantian categorical imperative. However, granted the under-determination of rationality, consistent undertaking of crucial human rights duties can be secured by emphasis on virtues [44]. Since inconsistency in discourse and practice of human rights also arise from ethnic favouritism and marginalisation and exclusion of other ethnicities, it is also feasible to explore the option of creating nation-wide inclusive sentiments. Nation-wide inclusive sentiments could ensure realisation of distribution of goods and duties in ways that progressively secure human rights.
The principle of progressive realization of human rights is spelled out in ICESCR article 2(1). It applies to states-parties obligations in ensuring socio-economic and cultural rights. The principle does not apply with respect to civil and political rights. Nevertheless, it is important that states-parties and human rights practitioners bear in mind that it should be read together with the principle of interdependence and interconnectedness of human rights (Vienna Declaration and Programme of Action, 1993, pt1, para5) [45]. Caution is required because there are divergent interpretations on most human rights. For example, while The EU Charter of Fundamental rights in Art.1 asserts that, "The dignity of the human person is not only a fundamental right in itself but constitutes the real basis of fundamental rights, [46] argues that there is no such a thing as a right to dignity. Mahony demonstrates that he knows that human dignity is stipulated in the preambles of most, if not all human rights covenants. on certain interpretations a critical aspect such human dignity striving to ensure socio-economic rights and bearing in mind the African states and human rights practitioners need to exercise Obviously, entail certain prerogatives in discourse and policies, such as awareness and bracketing of fundamental rights and striving to ensure non-violation of the latter--even in asserting the uniqueness of a particular state/society/community and grafting and implementing appropriate policies.

Capital features in most, if not all, activities of human life. However, to understand its operations and conceive mechanisms to check its nefarious consequences, it is necessary to conceive its permutations in terms of agencyidentity, viz. the agent that is identified as its owner and user. Accordingly, capital agency-identity yields the following: capitalist, corporation, state capitalism, and global capitalism. The pervasiveness of capital and its diverse permutations mean that the task of discoursing on the status of human rights is taunting and ensuring observance of human rights more so. The state, which is the primary duty-bearer of ensuring observance of human rights, is more than being simply one of the owners and users of capital. [7] argues that state capitalism is on the rise in Africa. This trend is problematic because states are not immune from the logic of capital and are bound to become human rights violators.

Apart from direct human rights violations by state capitalism, there are bound to arise subtle violations of human rights from state policies that are "based on the principle that cost and risk should be socialized, and profit privatized" [47]. In Africa, the practice of this principle and crony-capitalism perpetrates violations of human rights, which escape the attention of human rights monitoring agencies. For instance, in 2016, the Kenya government injected Ksh.1.2 billion into a retailer called Uchumi. This was despite the fact that citizens' access to quality primary education and access to higher education remain limited [48]. While such state interventions in the private sector are justified in terms of ensuring livelihoods of employees, in reality the actions continue the neo-patrimonial use of state machinery to secure and advance the interests of select elites. However, whenever the modern state engages in crony capitalism it does more than secure elite interests; it subtly enslaves the rest of the citizenry. This follows necessarily from the fact that the political elite capture "a larger slice of the economic pie and 
redistribute it to themselves at the expense of the rest of the economy" [49]. The expense that citizens suffer is in terms of states failing to undertake the primary duty of state-parties, viz. failure to promote and protect human rights. More specifically, "The poor, more than any other group, rely on basic public services. For vulnerable families, access to education and healthcare are important routes out of poverty" [50], but as already noted this is skewed along patron-client lines.

Thus, while the formation of states in Africa is generally conceived as progress from 'primitive' pre-state stage and whereas it is true that there are more elaborate institutions and processes of justice, such subtle but massive violations of human rights are largely unchecked. Modernity in Africa has heralded modes of expropriation that have created and exacerbated inequalities [51]. In fact, there is overwhelming evidence that the majority of people in Africa are totally unable to enjoy such basic human rights as food. In the last decades of the 20th Century, Shiva found that calorie intake had declined as follows: Kenya, 10.9 percent; Tanzania, 10.0 percent; and Ethiopia, 9.9 percent [52].

\section{CONCLUSION}

The inescapable conclusion from all the above is that while modernity started off with optimism born from the Enlightenment utopia of societies in which human beings enjoy dignified lives and a large range of civil, political, social, economic and cultural rights, it has evolved into an incubator of the phenomena of globalization and global capital which "deprive(s) the poor basic things: water, house or shelter, health, including nutritious food for survival" [53]. Meanwhile, the state--that agent that was conceived to be the primary guarantor of human rights--has become weak [54] and can hardly curtail corporate power "in order to preserve the conditions for individual autonomy" [55]. In Africa, the state is mostly a silent spectator of the violations of human rights unleashed by global capital, its agents accomplices of global capital, and a captive of the political elite who use it to enslave the rest of the citizenry. The latter dimension arises from the fact that African states' robust role in the economies engenders violations because in most cases policy decisions and expenditure of public resources do not meet the criteria of common good, viz. it is not distributively neutral, it is partisan, and is not extensionally adequate. Moreover, even though the 'end of history' has been hailed as the triumph of democracy [56], regular 'democratic' processes are, in many instances, processes of manufacturing state, regime, and leaders' legitimacy than anything more.

\section{ACKNOWLEDGMENT}

I thank the Center for Human Rights and Peace Studies, the University of Nairobi for offering me the opportunity to undertake this research.

\section{REFERENCES}

[1] Marx K. Capital: A Critique of Political Economy. Prog Publ Mosc. $1887 ; 1$.
[2] Verschraegen G. Human Rights and Modern Society: A Sociological Analysis from the Perspective of Systems Theory. J Law Soc. 2002;29(2):258-81.

[3] Luhmann N. Globalization or World society: How to conceive of modern society? Int Rev Sociol. 1997 Mar;7(1):67-79.

[4] Skeggs B. Values beyond value? Is anything beyond the logic of capital? Br J Sociol. 2014;65(1):1-20.

[5] Dahms HF. Critical Theory in the Twenty-First Century: The Logic of Capital Between Classical Social Theory, the Early Frankfurt School Critique of Political Economy and the Prospect of Artifice. In: Krier D, Worrell MP, editors. The Social Ontology of Capitalism [Internet]. New York: Palgrave Macmillan US; 2017 [cited 2021 Jun 27]. p. 4774. (Political Philosophy and Public Purpose). Available from: https://doi.org/10.1057/978-1-137-59952-0_3.

[6] Graber C.B, Teubner G. Art and Money: Constitutional Rights in the Private Sphere?. Oxf J Leg Stud. 1998 Mar 1;18(1):61-73.

[7] Taylor I. Emerging powers, state capitalism and the oil sector in Africa. Rev Afr Polit Econ. 2014 Jul 3;41(141):341-57.

[8] De Tocqueville A. Democracy in America. New York, Penguin Classics. 1835.

[9] Haugen HM. Human Rights Principles - Can They be Applied to Improve the Realization of Social Human Rights? Max Planck Yearb U N Law Online. 2011 Jan 1;15(1):419-44.

[10] Rendel M. Law as an Instrument of Oppression or Reform. Sociol Rev. 1975 May 1;23(1_suppl):143-71.

[11] Situma J. The Significance of Correlativity Doctrine and Some Contemporary Problems and Tendencies. Rev Hum Factor Stud. 2019 Jun;25(1):1-18.

[12] Larche J. Corruption in the NGO world: What it is and how to tackle it Humanit Pract Netw [Internet]. 1999; Available from: odihpn.org.

[13] Agarwala R. The Development of Labor under Contemporary Capitalism. Sociol Dev. 2018 Sep 1;4(3):239-60.

[14] Claassen R. Communication as Commodity: Should the Media be on the Market? [Internet]. 2011 [cited 2021 Jun 27]. Available from https://onlinelibrary.wiley.com/doi/epdf/10.1111/j.14685930.2010.00513.x.

[15] Baruah TD. Effectiveness of Social Media as a tool of communication and its potential for technology enabled connections: A micro-level study. 2012;2(5):10.

[16] Bialik M, Bogan M, Fadel C, Horvathova M. Character Education for the 21st Century: What Should Students Learn? 2015 Feb 1

[17] Rotherham A.J. $21^{\text {st }}$ Century Skills: the Challenges Ahead. Teaching for the $21^{\text {st }}$ Century.2009; 67(1):16-21.

[18] Corey P. Totality and Ambivalence: Postmodern Responses to Globalization and the American Empire. Eric Voegelin Society Meeting: $100^{\text {th }}$ APSA Annual Meeting. Louisiana State University. 2004.

[19] Layton R, Wallace G. Is culture a commodity. Camb Univ Press. 2006

[20] Chakrabarty D. Subaltern Studies and Postcolonial Historiography. Nepantla Views South. 2000;1(1):9-32.

[21] McNamara KR. Of intellectual monocultures and the study of IPE. In International Political Economy. Routledge; 2010.

[22] Bronk R, Jacoby W. Uncertainty and the Dangers of Monocultures in Regulation, Analysis, and Practice. 35.

[23] McAdams DP. The Psychology of Life Stories. Rev Gen Psychol. 2001 Jun 1;5(2):100-22.

[24] Sen A. A World of Extremes: 2001;3.

[25] P M. Globalization: Facts and Figures. IMF Policy Discussion. In: PDP/01/04. 2001.

[26] Joseph E. Stiglitz (2002) Globalization and Its Discontents - Ferri 2003 - Economic Notes - Wiley Online Library [Internet]. [cited 2021 Jun 27]. Available from: https://onlinelibrary.wiley.com/doi/abs/10.1046/j.03915026.2003.00107.x

[27] Rahim H, Abidin Z, Ping S, Alias M, Muhamad A. Globalization and its Effect on World Poverty and Inequality. Glob J Manag Bus. 2014;813

[28] Mudimbe VY. African Gnosis Philosophy and the Order of Knowledge: An Introduction. Afr Stud Rev. 1985;28(2/3):149-233.

[29] Legesse. Human Rights in African Political Culture." In The Moral Imperatives of Human Rights. Univ Press Americ Wash DC. 1980;123-38.

[30] Renteln AD. International Human Rights: Universalism Versus Relativism. Quid Pro Books; 2013. 276 p.

[31] Bozeman AB. The Future of Law in a Multicultural World. Princeton University Press; 2015. 248 p.

[32] Ilesanmi SO. Human Rights Discourse in Modern Africa: A Comparative Religious Ethical Perspective. J Relig Ethics. 1995;23(2):293-322. 
[33] Ishay M. What are human rights? Six historical controversies. J Hum Rights. 2004;3(3):14.

[34] Donders Y. Diversity in Europe: from Pluralism to Populism? Eur Popul Hum Rights. 2020 Jan 10;52-71.

[35] O'Neil T. Background Note 1 Neopatrimonialism and public sector performance and reform. 2007;19.

[36] von Soest C. How Does Neopatrimonialism Affect the African State? The Case of Tax Collection in Zambia. J Mod Afr Stud. 2007 Dec $1 ; 45: 621-45$.

[37] Ajulu R. Thinking Through the Crisis of Democratisation in Kenya: A Response to Adar and Murunga. Afr Sociol Rev Rev Afr Sociol. 2000;4(2):133-57.

[38] Auriol E, Gary-Bobo RJ. The More the Merrier? Choosing the optimal number of representatives in modern democracies [Internet]. VoxEU.org. 2007 [cited 2021 Jun 27]. Available from: https://voxeu.org/article/optimal-number-representatives-democracy.

[39] Bernards N. Placing African labour in global capitalism: the politics of irregular work. Rev Afr Polit Econ. 2019 Apr 3;46(160):294-303.

[40] Clark J. Soft Despotism is the Unique Threat to American Liberty. 2017.

[41] Check NA, Madise T, Majozi N, Hamada Y. The Integrity of Political Finance Systems in Africa: Tackling Political Corruption | International IDEA [Internet]. 2019 [cited 2021 Jun 27]. Available from: https://www.idea.int/publications/catalogue/integrity-political-financesystems-africa.

[42] Boone C. Land Conflict and Distributive Politics in Kenya. Afr Stud Rev. 2012;55(1):75-103.

[43] Boone C. Property and Political Order in Africa: Land Rights and the Structure of Politics [Internet]. Cambridge: Cambridge University Press; 2014 [cited 2021 Jun 27]. (Cambridge Studies in Comparative Politics). Available from: https://www.cambridge.org/core/books/property-and-political-orderin-africa/86A454E0C6FCE760199745807D6017A9

[44] Wanyama J, Odiemo L, Mutisya K. Under-determination of Rationality in Morality and Politics and the Necessity of Virtues. 2017 Dec 31.

[45] OHCHR | Vienna Declaration and Programme of Action [Internet]. 1993 [cited 2021 Jun 27]. Available from: https://www.ohchr.org/en/professionalinterest/pages/vienna.aspx

[46] O'Mahony C. There is no such thing as a right to dignity. Int J Const Law. 2012 Mar 30;10(2):551-74.

[47] Chomsky N. Resistance to Neoliberal Globalization. 2005;(1).

[48] Odhiambo G. Higher education in Kenya: an assessment of current responses to the imperative of widening access. J High Educ Policy Manag. 2016 Mar 3;38(2):196-211.
[49] Olson M. The Rise and Decline of Nations: Economic Growth, Stagflation, and Social Rigidities. Yale University Press; 2008. 286 p.

[50] MaGregor S. The Politics of Poverty: Elites, Citizens and States: Findings from ten years of DFID-funded research on Governance and Fragile States: 2001-2010. DFID Department for Development. 2010

[51] Murombedzi J. Inequality and natural Resources in Africa. UNESCO Publishing; 2016. $361 \mathrm{p}$.

[52] Assadi M. Discourse on Human Rights: Narratives Beyond "Political"." Indian J Polit Sci. 2011;72(2):377-86.

[53] Kälin W. Late modernity: Human rights under pressure? Punishm Soc. 2013 Oct 1;15(4):397-411.

[54] Herzog LM. Citizens' Autonomy and Corporate Cultural Power. 2020 [cited 2021 Jun 27]; Available from: https://core.ac.uk/reader/363146040

[55] Fukuyama F. The End of History?” The National Interest. 1989.

[56] Bellina S, Darbon D, Eriksen SS, Sending OJ. The Legitimacy of the State in Fragile Situations. Norad [Internet]. 2009 [cited 2021 Jun 27]; Available

https://norad.no/en/toolspublications/publications/2009/thelegitimacy-of-the-state-in-fragile-situations/.

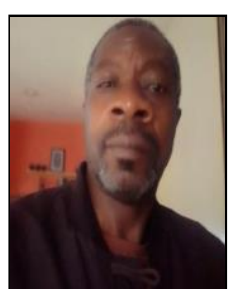

Joseph Situma was born in Western Kenya in 1965. He undertook his primary education at Namawanga Primary School and is an alumni of Chesamisi High School, Kakamega High School and University of Nairobi. He holds a B.A. (Hons) (University of Nairobi), M.A. (University of Nairobi) and Ph.d. (University of Nairobi).

He has served as tutorial fellow and lecturer at University of Nairobi and risen to the position of senior lecturer in the Department of Philosophy and Religious Studies, at University of Nairobi.

Dr. Situma, is the author of various novels, among them The Mysterious Killer, Nairobi, Africawide Network, 2000, and The Gift of the Night, Nairobi, Marimba, 2010. His published articles include, "Underdetermination of rationality in Morality and Politics and the Necessity of Virtues (in Africa)," Journal of Gleanings from Academic Outliers, Vol.6 No.1 and "The Significance of Correlativity Doctrine and some Contemporary Problems and Tendencies," Review of Human Factor Studies, Vol.25 No.1. He is currently researching transitional justice mechanisms in Africa. He is a founding member of The Center for Human Rights and Peace Studies, University of nairobi. 